DOI: https://doi.org/10.31392/NZ-npu-144.2019.02

УДК 378:37.091.12.011.3-051:62/64

Белан Т. Г.

\title{
ПСИХОЛОГО-ПЕДАГОГІЧНА ПІДГОТОВКА МАЙБУТНІХ ПЕДАГОГІВ-ІНЖЕНЕРІВ
}

У статті описана психолого-педагогічна підготовка майбутніх педагогів-інюеенерів у закладі вищої освіти. Охарактеризовані навчальні курси психолого-педагогічного чиклу. Значна увага приділена різним видам педагогічної практики, яку студенти проходять у прочесі навчання. Описані основні завдання, які постають перед майбутніми педагогічними працівниками на період проходження педагогічної практики. Зазначено, що знання з психолого-педагогічних дисииплін стають більш конкретними, дісвими під час проходження педагогічної практики.

Ключові слова: психолого-педагогічна підготовка, професійна підготовка, майбутній педагогінженер, педагогічна практика.

Профресійна діяльність педагога-інженера включає інженерну і педагогічну складові. Метою педагогічної діяльності $€$ профресійне навчання і виховання підростаючого покоління, а метою інженерної діяльності - розробка виробничо-технологічної документації, забезпечення виробничого процесу в навчальних майстернях, обслуговування матеріально-технічної бази лабораторій і кабінетів, освоєння нових технологічних процесів і техніки та ін. [3, с. 183]. Педагогічну діяльність педагогів-інженерів забезпечує психологопедагогічна, методична, професійна підготовки майбутніх педагогів-інженерів у закладах вищої освіти. Теоретичні знання, які отримують студенти під час вивчення дисциплін психолого-педагогічного циклу, необхідні для майбутньої педагогічної діяльності педагогів-інженерів, а також знадобляться у повсякденному житті.

Проблеми професійної підготовки майбутніх педагогів-інженерів розглядали у своїх дослідженнях науковці: Н. Брюханова, І. Герніченко, Р. Горбатюк, І. Каньковський, 3. Курлянд, О. Ляска, С. Ткачук.

Проаналізувати психолого-педагогічну підготовку майбутніх педагогівінженерів спеціальностей “Професійна освіта. Транспорт" та “Професійна освіта. Харчові технології”.

Процес профресійної підготовки майбутніх педагогів-інженерів спеціальності "Професійна освіта. Транспорт" та "Професійна освіта. Харчові технології" складний та далеко нелегкий. Під час навчання у закладах вищої освіти студенти збагачуються теоретичними знаннями, практичним досвідом та методологією наукового пізнання.

Профресійно-педагогічна підготовка педагога-інженера - це організований, систематичний та цілеспрямований процес формування та розвитку профресійно-педагогічних знань, умінь, навичок, якостей студента, необхідних йому для успішної реалізації майбутньої інженерно-педагогічної діяльності [2, c. 140$]$. 
Психолого-педагогічна підготовка займає значну частину в навчальному плані майбутніх педагогів-інженерів і передбачає вивчення таких навчальних дисциплін: “Психологія", "Вступ до спеціальності", “Педагогіка”, “Психологія вищої школи", “Педагогіка вищої школи”, "Педагогічна майстерність", “Профресійна педагогіка", "Теорія і методика професійної освіти". Також в психолого-педагогічну підготовку майбутніх педагогів-інженерів входить педагогічна практика.

На заняттях навчальної дисципліни "Вступ до спеціальності" відбувається орієнтування студентів стосовно змісту педагогічної діяльності, її сутності та ролі в сучасному суспільстві, розглядаємо основні шляхи і методи набутя педагогічного досвіду. Під час вивчення навчальної дисципліни виховуємо інтерес до особистості учня, особистості педагога і педагогічної діяльності. Завдання, які вирішуємо під час вивчення дисципліни "Вступ до спеціальності" такі: допомогти студентам адаптуватися до навчально-виховного процесу у закладах вищої освіти; засвоїти зміст педагогічної діяльності, ії̈ суспільне значення; сприяти здобуттю знань, виробленню вмінь і навичок для успішної самореалізації у майбутній профресійній діяльності.

Навчальний курс "Психологія" розкриває психологічну суть особистості, що знаходить свій прояв у психічній діяльності, у вчинках, у формуванні рис характеру, розвитку здібностей, у міжособистісних стосунках і т.п. Вивчаючи психіку людини, студенти ознайомлюються з особливостями всіх психічних процесів, а саме уваги, уяви, сприймання, пам'яті, мислення, емоцій та почуттів. Кожна тема, яка вивчається на заняттях, взаємопов'язана 3 майбутньою педагогічною діяльністю. На заняттях розглядаємо взаємозв'язок соціального і психічного в житті окремої людини і групи людей, а також соціально-психологічні явища, які виникають в процесі взаємодії між людьми і групами. Цілком очевидно, що творча робота вчителя передбачає вміння вивчати стан колективу, виявляти та усувати конфлікти в ньому, об'єднувати учнів, спонукати їх до серйозної праці. На практичних заняттях студенти проводять психодіагностичні методики, що стосуються взаємовідносин у колективі, і навчаються складати психолого-педагогічну характеристику групи.

Глибоке розуміння психології впливає на формування особистості студента як майбутнього педагога, допомагає розвивати такі позитивні риси характеру як наполегливість, справедливість, щедрість, доброзичливість, чесність, принциповість.

У процесі вивчення теорії педагогіки студенти опановують як теорію навчання і виховання учнів, так і певні практичні вміння та навички, а саме: підбирати потрібну літературу та користуватися нею, аналізувати певні педагогічні ситуації й давати їм правильну оцінку. Особлива увага приділяємо розгляду різних підходів в педагогіці до навчання - проблемне навчання, програмоване навчання, розвиваюче навчання та розглядається сутність процесу виховання та основні його напрями.

На заняттях $з$ методики виховної роботи студенти ознайомлюються 3 сутністю, принципами, напрямками виховної роботи, теоретичними основами 
методики колективного творчого виховання, методикою педагогічної діагностики; навчаються планувати виховну роботу в класі, літньому таборі, організовувати гурткову роботу; ознайомлюються з особливостями роботи 3 обдарованими та важковиховуваними учнями. Мета цього курсу - формувати у студентів знання і вміння в галузі теорії, методики і техніки виховної роботи, виховувати у студентів повагу і любов до дітей, вимогливість до них і до себе; розвивати інтерес і творче ставлення до роботи з учнями; фрормувати вміння творчо вирішувати конкретні виховні задачі.

Зміст курсу "Педагогічна майстерність" відкриває перед студентами уявлення про цілісну структуру професійної діяльності вчителя, фрормує професійно-педагогічну направленість особистості майбутнього вчителя, сприяє розвитку педагогічної техніки, педагогічних здібностей та стимулює творче вирішення практичних задач учителя. Вивчення курсу відбувається в умовах, наближених до професійної діяльності (розв'язання педагогічних задач, мікровикладання, моделювання педагогічних ситуацій). Це дає змогу аналізувати й оцінювати вихідні настанови, потреби, орієнтації майбутніх учителів, що впливає на вибір ними стратегій поведінки в ситуаціях педагогічної взаємодії. Метою викладання курсу педагогічної майстерності $€$ формування в студентів потреби й уміння в неперервному педагогічному вдосконаленні, вироблення в них практичної та педагогічної готовності до професійної діяльності вчителя технологій.

На заняттях з навчальної дисципліни “Професійна педагогіка” студенти досліджують основні проблеми сучасної неперервної професійної освіти в Україні, аналізують принципи професійного навчання та виховання особистості, на заняттях створюємо умови для формування професійно важливих і соціально значимих якостей особистості як педагога-інженера. Також розглядаємо структура уроку, аналіз уроку, методи навчання та методи виховання учнів, розкриваємо значення та основні форми методичної роботи в школі, шляхи підвищення кваліфікації та атестація педагогічних працівників, основну увагу приділяємо структурі закладу професійної освіти та нормативним державним документам в галузі освіти.

Навчальна дисципліна "Теорія і методика професія освіти" забезпечує теоретичні знання і практичну підготовку майбутніх інженерів-педагогів до творчого забезпечення педагогічного процесу в закладах професійно-технічної освіти. На заняттях у студентів формуємо професійні знання, уміння та навички проектування та здійснення теоретичного й виробничого навчання в закладах професійної освіти.

У професійній підготовці майбутніх педагогів-інженерів значне місце займає педагогічна практика. За навчальним планом кожний вид педагогічної практики $є$ підсумком вивчення певного циклу дисциплін. Створена система педагогічних практик у професійній підготовці майбутніх педагогів-інженерів передбачає єдність та наступність усіх видів практик та їх взаємозв'язок 3 психолого-педагогічними дисциплінами.

Педагогічна практика як фрорма професійного навчання у вищому 
педагогічному навчальному закладі спрямована на практичне пізнання закономірностей і принципів професійної педагогічної діяльності, на реалізацію їх в ході практичної діяльності зі студентами-бакалаврами, на теоретичне осмислення педагогічних явищ і фактів. У ході педагогічної практики знання 3 психолого-педагогічних направляємо в русло практичних дій, на розв'язання конкретних педагогічних задач. Педагогічна практика дає можливість пізнати всесторонньо педагогічний процес, педагогічні явища, фрорми і методи навчально-виховної роботи з учнями закладу професійної освіти [1].

Першу педагогічну практику (пропедевтичну) студенти проходять у четвертому семестрі. Зміст пропедевтичної практики включає два модулі. Перший модуль включає в себе завдання з педагогіки (організація навчальної і виховної роботи, ознайомлення 3 матеріальною базою школи та 3 оформленням школи, матеріальне та дидактичне оснащення занять, навчальна робота, аналіз уроків, проведених учителями), другий модуль завдання 3 психології (психолого-педагогічна характеристика процесу засвоєння знань учнями, психолого-педагогічна характеристика учня).

Вивчення психології допомагає навчитися студентам під час педагогічної практики усвідомлювати явища педагогічного процесу з точки зору психології: проаналізувати поведінку і діяльність педагога та учнів (як врахувати вікові та індивідуальні особливості учнів при викладі нового матеріалу та його відтворенні), а також виявити самостійність у судженнях, уміння самостійно підходити до розв'язання педагогічних задач, що виникають у педагогічному процесі під час проходження практики.

Педагогічна практика - це перша спроба опанувати професію вчителя, яка сприяє кращому оволодінню практичними вміннями та навичками в процесі навчальних занять, проводиться в умовах майбутньої професійної діяльності, проходить в тісному зв'язку з теоретичним курсом .

Основним завданням пропедевтичної практики є поєднання теоретичної підготовки студентів з дисциплін, які вивчили (особливо 3 психології) із практичним застосуванням набутих знань у роботі з учнями, а також формування у студентів науково-дослідницького підходу до педагогічного процесу, вмінь і навичок проведення навчальної та позакласної виховної роботи (завдання на кожний день перебування студентів в школі, психологопедагогічний аналіз уроку за схемою, психолого-педагогічна характеристика учня з використанням пакета психодіагностичних методик).

Навчально-педагогічна практика студентів третього курсу включає розроблені завдання для студентів на весь період практики. Розроблені завдання ускладнені в порівнянні із завданнями пропедевтичної практики, 3 метою поетапної адаптації студентів до умов майбутньої професійної діяльності. До системи завдань навчально-педагогічної практики студентів третього курсу входять такі завдання: ознайомлення зі школою, кабінетом, їх оформленням; бесіда з адміністрацією школи, класним керівником, вчителем технологій; аналіз уроків та виховних годин, які проведені учителями. 3 метою поетапного пристосування до умов майбутньої професії студенти проводять 
пробний урок з виробничого навчання 3 наступним його обговоренням 3 учителем-наставником та виховну годину 3 наступним ії обговоренням 3 класним керівником.

Отриманий досвід під час педагогічних практик на молодших курсах $\mathrm{i}$ поглиблені теоретичні знання студенти використовують в процесі проходження активної педагогічної практики, коли виконують функції вчителя професійного навчання і класного керівника.

Саме під час різних видів педагогічної практики на молодших курсах студенти збагачують свої спостереження, відчувають практичну значущість професійних знань, потребу оволодіння ними. Знання з суспільних, психологопедагогічних і спеціальних дисциплін стають більш конкретними, дієвими. У процесі педагогічної практики з'являється можливість перевірити себе на правильність вибраного життєвого шляху, відповідність особистісних якостей вимогам педагогічної професії, любов чи їі відсутність до дітей, уміння відстоювати свою точку зору, вміння організувати колектив, поєднати навчально-практичні завдання з предметів психолого-педагогічного циклу 3 конкретною практичною роботою в школі. Саме під час ознайомлення студентів із навчально-виховним процесом у закладах професійної освіти відбувається початок процесу адаптації студентів до майбутньої професійної діяльності педагога-інженера.

Активна педагогічна практика $€$ логічним продовженням педагогічних практик на молодших курсах, з послідовним ускладненням завдань, з метою адаптувати практикантів до умов майбутньої профресії.

На четвертому курсі передбачено проведення системи уроків і позаурочних занять (гуртка, олімпіади, турніру) з виробничого навчання, системи виховної роботи в залежності з планом класного керівника. В центрі уваги урок - як основна форма організації навчально-педагогічного процесу. Майбутнім педагогам-інженерам потрібно усвідомити урок як одиницю навчального процесу, зрозуміти його завдання, функції, методику, фрорми організації і контролю, оцінити його якість, ефективність. Самостійне проведення уроків веде до узагальнення знань із психології, педагогіки та методики.

Цей вид педагогічної практики відрізняється від попередніх, її підґрунтям є активне включення студентів у професійну педагогічну діяльність. Усе, що раніше вивчали по частинах, в процесі педагогічної практики складається в єдиний цілеспрямований процес, виконавцями якого $є$ майбутні педагогиінженери.

У процесі педагогічної практики педагоги-інженери проводять уроки виробничого навчання, виховні години, профорієнтаційні заходи, організовують екскурсії, відвідують уроки педагогів-наставників.

Педагогічна практика повинна стати початком творчого вивчення особистості школяра на різних етапах її розвитку, що потребує опрацьовування дослідницьких методів, особливо тих, які доступні кожному вчителю: спостереження, бесіда, анкетування, тестування, природній 
експеримент. Майбутньому вчителю необхідно аналізувати результати виховання, визначати ступінь розвитку тих чи інших індивідуальних якостей учнів, оцінювати особистість учня з різних кутів зору, у різних життєвих ситуаціях.

Успіх педагогічної практики залежить від організації педагогічної практики; взаємозв'язку закладу вищої освіти із закладом професійно-технічної освіти; рівня теоретичної і практичної підготовки студентів.

Висновки. Вивчення психолого-педагогічних дисциплін повинно бути побудовано в логічному взаємозв'язку лекційних і практичних занять із завданнями педагогічної практики. Знання 3 цих дисциплін допоможуть молодому педагогу-інженеру вирішити як проблемну ситуацію, так і конфлікти у педагогічному процесі. В сучасних умовах педагог-інженер повинен знати особливості організації навчально-виховного процесу закладу професійнотехнічної освіти, володіти системою знань необхідних при проведенні уроків, проводити профорієнтаційну роботу, враховуючи інтерес учнів, здійснювати виховну роботу.

\section{Використана література:}

1. Белан Т. Г. Роль педагогічної практики в професійній підготовці магістрантів. Bicник Чернігівського національного педагогічного університету. Випуск 125. Чернігів, 2015. С. 128-131.

2. Ляска О. П. Професійно-педагогічна підготовка інженерів-педагогів в аграрному вузі. Збірник наукових пращь Кам'янещь-Подільського наиіонального університету. Випуск 20. Кам'янецьПодільський, 2014. С. 139-142.

3. Ткачук С. І. Педагогічні аспекти підготовки майбутніх інженерів-педагогів харчових технологій у педагогічних вищих навчальних закладах. Наукові записки Тернопільського нащіонального педагогічного університету. Випуск 2. Тернопіль, 2016. С. 181-186.

\section{References:}

[1] Belan T.H. (2015). Rol pedahohichnoi praktyky v profesiinii pidhotovtsi mahistrantiv. [The role of pedagogical practice in the training of undergraduates]. Visnyk Chernihivskoho natsionalnoho pedahohichnoho universytetu. Bulletin of Chernihiv National Pedagogical University. Issue 125. P. 128-131.

[2] Liaska O. P. (2014). Profesiino-pedahohichna pidhotovka inzheneriv-pedahohiv $v$ ahrarnomu vuzi. [Professional and pedagogical training of engineers-educators in agrarian university]. Collection of scientific works of Kamenets-Podilsky National University. Zbirnyk naukovykh prats KamianetsPodilskoho natsionalnoho universytetu. Vypusk 20. S. 139-142.

[3] Tkachuk S. I. (2016). Pedahohichni aspekty pidhotovky maibutnikh inzheneriv-pedahohiv kharchovykh tekhnolohii u pedahohichnykh vyshchykh navchalnykh zakladakh.[Pedagogical aspects of training of future engineers-educators of food technologies in pedagogical higher educational establishments]. Scientific notes of Ternopil National Pedagogical University. Naukovi zapysky Ternopilskoho natsionalnoho pedahohichnoho universytetu. S. 181-186.

\section{БЕЛАН Т. Г. Психолого-педагогическая подготовка будущих педагогов-инженеров.}

В статье описана психолого-педагогическая подготовка будущих педагогов-инженеров в высшем учебном заведении. Охарактеризованные учебные курсы психолого-педагогического ичикла. Значительное внимание уделено разныим видам педагогической практики, которую студентьы проходят в прочессе обучения. Описанные основные задания, которые появляются перед будущими педагогическими работниками на период прохождения педагогической практики. Отмечено, что знания психологопедагогических дисииплин становятся конкретными, действенными во время прохождения педагогической практики.

Ключевые слова: психолого-педагогическая подготовка, профессиональная подготовка, будуший педагог-инженер, педагогическая практика. 


\section{BELAN T. Psychological and pedagogical training of future engineering educators.}

The article describes the psychological and pedagogical training of future pedagogical engineers in higher education. The training courses of the psychological-pedagogical cycle, namely "Psychology", "Introduction to the specialty", "Pedagogy", "Pedagogical skill", "Professional pedagogy", "Theory and methodology of vocational education" are characterized.

It is emphasized that understanding of psychology influences the formation of the student's personality as a future teacher. It helps to develop such positive character traits as perseverance, justice, generosity of kindness, honesty, principle. Students develop professional knowledge, skills and skills of designing and implementing theoretical and industrial training in vocational education institutions in pedagogical subjects.

Pedagogical practice plays a significant role in the professional training of future engineering teachers. According to the syllabus, each type of pedagogical practice is a result of studying a certain cycle of disciplines. The created system of pedagogical practices in the professional training of future teacher-engineers provides the unity and continuity of all types of practices and their relationship with the psychological and pedagogical disciplines.

The main tasks that future pedagogical staff are facing for the period of pedagogical practice are described. It is stated that the knowledge in the psycho-pedagogical disciplines become more specific, effective during the course of pedagogical practice.

Keywords: psychological and pedagogical training, vocational training, future teacher-engineer, pedagogical practice.

DOI: https://doi.org/10.31392/NZ-npu-144.2019.03

УДК 373.3.091.33:37.016:3

Борисов В. В., Лупінович С. М., Борисова С. В.

\section{ВИКОРИСТАННЯ ІННОВАЦІЙНИХ МЕТОДІВ У ПОЧАТКОВІЙ ШКОЛІ ПРИ ВИВЧЕННІ ПРЕДМЕТУ “Я У СВІТІ"}

У сучасному освітньому середовищі якісне подання інформації та ї візуалізачія не може здійснюватися без використання засобів $і$ можсливостей, які надають комп'ютерні технологї та Інтернет. Сучасні інформачійно-комунікаційні технологї створюють иирокі можливості для використання ӥх в навчальному прочесі. Освіта - важливий фактор формування та розвитку активної $і$ творчої особистості. Украӥнська система освіти знаходиться на стадії реформування, щуоб адекватно та вчасно відповідати на запити суспільства. Нові вимоги до сучасноїлюдини, громадянина, професіонала автоматично висувають нові вимоги до педагога. Він має одночасно виконувати декілька ролей: розробник навчальних програм, тренер, фасилітатор, презентатор, консультант, дослідникі т.д.

Інтегративний курс “Я у світі" для 3-4 класів загальноосвітніх икіл обіймає історичні, етнографічні, політичні та правові матеріали. Він дозволяе вчителю широко використовувати педагогічні інноващії.

Інновація в освіті - це продукт творчого прочесу, який піднімає навчання на якісно новий рівень.

E-learning ma m-learning, враховуючи сучасні світові тендениї, мають стати частиною навчального прочесу у молодшій иколі. Теоретичний матеріал з предмету “Я у світі" краще запам'ятається, якщо буде супроводжуватись аудіо-, відеоматеріалами, можслиістю закріплювати знання за допомогою мобільних додатків. Осучаснення освіти буде сприяти підвищенню мотиваиії учнів тапокращенню результатів навчання.

3 метою активізацї взаємодії учнів на уроках та в позаурочний час ваюливо використовувати інтерактивні технології освіти.

Використання педагогічних інновачій, різноманітних методів та прийомів навчання, сучасних інформаційно-комп'ютерних технологій дозволяе урізноманітнити навчальний прочес, зробити його 